\title{
A Framework for the Strategic Management of Information Technology
}

\author{
Dhiya Abdullah Al Wazzan \\ Arab Academy for Scientific Research, Kuwait
}

\begin{abstract}
The complementary between IT as a competitive factor and strategic management is very important for gaining competitive advantages. This paper explores factors related to strategy and IT that should be considered for the strategic analysis of IT as a competitive factor and proposes a framework for Strategic Technology Management (STM). The research is conducted by means of quantitative and qualitative analysis of data. The framework is expanded and validated through inference to findings of large and small to medium-sized enterprises through interviews, finally ending on theory matching. The results of the analysis show that the strategic management of information technology is a continuous process of evaluation and change and that the alignment between factors such as competitive environment, competitive strategies (business and IT strategies), competitive outcome, and competitive factors gain competitive advantages for industrial companies.
\end{abstract}

Key Words: strategic management, information technology (IT), competitive environment, competitive advantages

\section{Introduction}

Recently, Internet made possible data processing between customers, producers and suppliers, as well as be-tween customers and producers. Since both customers and competitors connect to the Internet, companies have to consider the Internet as a strategic competitive resource. IT is used as a source of competitive advantages because it solves problems such as geographic distance, transaction costs, availability in time, and global in-tercommunication. Therefore, in order to be more competitive and increase market shares, companies require fast and updated information. Information technology (IT) plays an important role in supporting the organiza-tion to conduct its business processes. Most organizations in all sectors of industry, commerce, not-for-profit, and government are now fundamentally dependent on their information systems (IS) and information technol-ogy (IT). In industries such as telecommunications, media, entertainment, gambling and financial services, where the product is already, or is being increasingly, digitized; the very existence of an organization depends on the effective application of IT. A number of forces affect the pace and effectiveness of progress in using IT and in delivering operational and strategic benefits. The relative importance of each factor varies over time, and will also vary from one organization to another. These factors include:
1- The capabilities of the technology and the applications those are feasible.

2- The economics of acquiring, deploying and maintaining the technology: applications, services and infra-structure.

3- The skills and abilities available, either in-house or from external sources, to design and implement the applications

4- The skills and abilities within the organization to use the applications and information;

5- The capability to manage any organizational changes accompanying technology deployments;

6- The pressures on the particular organization or its industry to improve performance or adapt to changing circumstances, such as a new regulatory environment or 'digital disruption'.

Many researchers (Sällberg, Henrik, 2004) today accept that IT is an important factor for competitive ad-vantages. However, many managers have problems matching the developments of (IT), and have difficulties getting competitive benefits from it (Keller, Christina, 2005).

This article is distributed under the terms of the Creative Commons Attribution License, which permits unrestricted use and redistribution provided that the original author and source are credited. 
In recent years much research (Wang, Zhiping, 2004) have focused on the potential to create competitive advantages that resides primarily in the Strategic Technology Management (STM). Recent writings argue that the management information Technology (IT) function should no longer be viewed in its traditional role, but in terms of a strategic role for exploiting ISbased competitive advantages. Both competitive environment and IT are important factors to consider for Strategic Technology Management (STM) research. The reason to focus on strategic management is that com-petition based on IT changes constantly. Therefore, in order to create competitive advantages managers need to combine and adjust business strategies and IT factors to meet the demands of competition. One way to in-crease knowledge of Strategic Technology Management (STM) can be by integrating strategic management factors and IT factors into the same framework of analysis In this article, the researcher explores IT from the perspective of strategic management.

From a strategic management perspective, Strategic Technology Man-agement (STM), research can be conducted by proposing theories, models, or frameworks of analysis. While theories and models are used to explain few factors (Porter 1991), frameworks are used to explain many fac-tors. Much strategic management research is represented by using frameworks. Although, frameworks have been accused of lacking practical use, they have been recognized as good management tools for developing strategic thinking and for dealing with the future. Consequently, managers use strategic frameworks as tools to communicate visions and to achieve future goals considering that Strategic Technology Management (STM) may be related to many factors, the expansion of knowledge through a framework is selected as the most ap-propriate approach. The development Information Technology in educational institutions led to the use of IT which has entered and become an alternative in the management and implementation of activities of academic activities.

\section{Research Problem}

Strategy and IT research has been extensively discussed during the past 40 years. Two scientific disciplines Management Science (MS) and Management Information Science (MIS) investigate the importance of IT as a competitive factor. However, although much research is available in both disciplines, it is still difficult to explain how to manage IT to enable competitive advantages. One reason is that MS research focuses on strategies and competitive environments but avoids the analysis of IT. Another reason is that MIS research focuses on IT as a competitive factor but avoids the analysis of the competitive environment. Consequently, there is a gap of knowledge in the understanding of the Strategic Technology Management (STM). The problem is that there is little research that contributes to holistic understanding of Strategic Technology Management (STM) that can be applied to the characteristics of IT today (Cöster, Mathias, 2005). Consequently, there is a need for further research to develop updated frameworks that can consider both factors. Moreover, further research is needed to update factors of IT that can apply to global competitive scenarios.

\section{Purpose of the study}

The Purpose of the study is to: 1) Define what elements are needed for Strategic Technology Management (STM) and 2) - Develop a framework for exploring the strategic management of information technology in competition.

\section{Research Questions}

The main question is what are the factors related to Strategic Technology Management (STM) and what is their effect on competitive outcome? To answer this question, three sub- questions need to be answered:

1) Which factors are related to technology management and affect competition?

2) Which factors are related to strategic management and affect the competition?

3) What is the relation between strategic and technology management factors and how do they affect competition?

\section{Significance of the study}

This research contributes to strategic management research by clarifying the relationships between strategic management, competitive environment, and IT as competitive factor into a holistic framework for strategic analysis. The framework proposed is valuable not only for business managers and for IT managers, but also for academics. The framework is designed to understand the relationship between competitive elements during the process of strategic analysis prior to the formulation of competitive strategies. Moreover, it can also be used as a communication tool between managers, in order to achieve alignment among company strategies. To academics, this thesis presents the state-of-the-art related to strategic management research; it can also be a valuable reference for strategic managers, as well as researchers interested in the strategic management of IT. 


\section{Delimitations of the Study}

This study is delimited to: -Management Science (MS) and Management of Information Systems (MIS) as parent disciplines for SMIT.

-Research conducted in the discipline of Management Science.

-Factors related to strategic analysis and strategic choices.

The consideration of competitive strategies. -

Factors those are important to consider in achieving competitive advantages -

\section{Literature Review}

\section{Definition of terms}

Strategy from different perspectives: According to Andrews (1980), "strategy is the pattern of decisions in a company that determines and reveals its objectives, purposes or goals, [which] produces the principal policies and plans for achieving those goals, and defines the range of business the company is to pursue, the kind of economic and human organization it is or intends to be and the nature of the economic and noneconomic contribution it intends to make to its shareholders, employees, customers and communities". So, we can say strategy can be related to any goals that define the future of the business with special focus on economic goals. Strategy also is the act of aligning a company and its environment. That environment, as well as the firm's own capabilities is subject to change. Thus the task of strategy is to maintain a dynamic, not a static balance (Porter 1991). Porter (1991) focuses on strategy as the dynamic interaction between a business organization's capabilities and its environment. Moreover, Porter argues that strategy balance the relations between the organization and its environment.

Cardullo (1996) defines strategy from the perspective of Management Technology as: used to allocate factors based on the organization's needs and should manage: 1). Core competencies and shortcomings. 2). Unanticipated changes in the environment and 3). Contingent moves by competitors or agents.

This definition adds some factors to the role of strategy and highlights the complexity of the strategy role and stresses the need to allocate factors in the organization.

Management from different Perspectives: From the perspective of Management Science, Management definitions describe either the actions or role of the manager. Johannsen \& Page (1986) define Management as: 1) Effective use and coordination of factors such as capital, plant, materials and labor to achieve defined objectives with maximum efficiency.
2) people responsible for directing and running an organization.

This definition, management may be interpreted in two ways: as the actions done by the manager, or as the manager or the people that execute those actions. Moreover, this definition also relates management to the effective coordination of [business] factors in order to achieve specific goals. The role of the manager is to achieve different goals and one of these goals may be to enable competitive advantages. However, the achievement of competitive advantages is not traditionally related to management, but rather to strategic management.

From the perspective of Management Information Systems, definitions of Management are always related to the management of (IT) or (IS) as technology. Lundeberg, et al., (1995) define (Management of Information Systems as an academic field) as the study of structures and processes related to the use of information technology by persons in business processes.

This definition refers to the management of "information systems." This is because, most of the IT developments in 1980s (the date of this definition) relate to information systems. Lundeberg's, definition highlights some components of MIS perceptions of management such as: information technology, business processes, and persons.

Similarities and Differences between "Strategy" and "Management": From Previous definitions for both "Strategy" and "Management", we can extract that; One similarity is that the role of both strategy and management is to select resources and achieve economic goals. One of the differences is that while strategy is concerned with the achievement of strategic goals, management is concerned with the effective use of resources. Another difference is that while strategy definitions usually focus on the role of competitive strategies, management definitions usually focus on the role of the manager as a coordinator of resources.

Technology: Encyclopedia Britannica (2006) defines Technology as the development over time of systematic techniques for making and doing things. According to Cardullo (1996) technology refers to an art or craft, and loggia, meaning an area of study; thus, technology means the study or science of crafting". Craft is by definition a synonym for art, and therefore it may be manifest in different forms. Considering technology as an art means that technology expresses the creativity of its designer and consequently changes with every designer. Therefore, technology may have as many different manifestations as the amount of designers, and the manifestations of technology can be sometimes innovative and revolutionary.

"We define information technology as a firm's total investment in computing and communications technology. This includes hardware, software, 
telecommunications, the myriad of devices for collecting and representing data (such as supermarket pointof- sale and bank automatic teller machines), all electronically stored data, and the people dedicated to providing these services. It includes the information technology investments implemented by internal groups (insourced) and those outsourced by other providers, such as IBM Global Services or EDS (Weill \& Broadbendt, 1998).

Strategic Technology Management (STM): The Strategic Technology Management (STM) is related to the achievement of a business organization's objectives by charting, planning, and designing the uses of information technologies and information strategies to enable advantages in the competitive environment.

This definition implies that STM involves two activities. One activity is the strategic analysis of the competitive environment, and another activity is the management of information technology as a competitive factor (Flodström, 2006).

STM is related to the research of Strategy, Management of Information Technology, Information Technology, and IT Strategy. The purpose of this research, the perspectives of two disciplines are in focus: Management Science (MS) and Management of Information Systems (MIS). The discipline of Management Science provides knowledge about factors such as strategic management, competitive environment, competitive strategies, and competitive f factors. The discipline of the Management of Information Systems provides knowledge about factors of IT and IT strategies in competition.

\section{Information Technology Research}

The Nature of Information Technology (IT) Research: Since information technology (IT) influences many areas, many scientific disciplines study issues related to IT, and therefore much research can be found (Ball 1982, p. 30). Because IT affects many disciplines, research into the management of IT has been conducted since 1960 from several disciplines such as the Management of Information Systems, Economics, Management Organizational Behavior, Computer Science, Decision Science, and Management Science. Consequently, many disciplines today pursue research related to IT. This forms the interdisciplinary nature of IT Research. IT research is pursued within many disciplines, and therefore, may be influenced by many dominant theories within those disciplines. IT research does not have own research theories or methods, but combine theories or methods from other disciplines. However, the research of IT is studied in two major disciplines: the discipline of Computer Science (CS), and the discipline of Management Information Systems (MIS). Davis (1991, p.10) discusses the roots of
IT in relation to the field of computer science. He argues that even when the fields of Computer Science, and the field of Management of Information Systems, study the same object (IT), there are differences in the way the disciplines approach IT. The differences are related to the context for the use of knowledge, academic context, key issues, and research paradigms. For example the field of Management of Information Systems (MIS) studies organizations, design, implementation, management of human/ machine systems as key issues.Its research paradigms are organizational and behavioral. While the field of Computer Science concentrates on Algorithms, computational methods, and structures for modeling data and programs as key issues.

The Nature of IT Strategy Research: IT strategy research has been influenced by other disciplines, such as Management Science (Porter, 2001), Computer Science, and Organization. Developments in the discipline of Computer Science affect IT strategies. This is because the development of new technologies affects the results of IT strategies. This is because new technological developments increase the choices of IT, which affect IT strategies. Organization theories also influence IT strategy research with theories such as Group interaction, Knowledge Management, and Organizational Learning (Orlikowski, 1992a, 1995, 2000).

IT strategy research has interdisciplinary nature which is influenced by theories from disciplines such as management of information systems, management science, economy, organization, and computer science. However, the focus of this research is the process of strategic analysis and its contribution related to strategic management, i.e. framework for strategic analysis, the discipline of Management Science is selected as a parent discipline for strategy issues related to STM.

A Classification of the Strategic Uses of IT: The four main types of strategic system are those applications that: 1) share information via technology-based systems with customers/consumers and/or suppliers and change the nature of the relationship. 2). produce more effective integration of the use of information in the organization's value-adding processes; 3). Enable the organization to create, develop, produce, market and deliver new or enhanced products or services or new value propositions based on information; and 4) augment people's cognitive processes in generating knowledge and insight from information; they provide executives, management and professionals with information to support the development, implementation and evaluation of strategies.

A similar approach was adopted by Venkatraman (1991) in assessing how the strategic benefits from IT resulted from increasing the extent of business change 
(and risk). He described three types of 'revolutionary' uses of IT, which require considerable transformation in terms of what the organization does or how it does it: Business process redesign - using IT to realign business activities and their relationships to achieve performance breakthroughs.

Business network redesign - changing the way information is used by the organization and its trading partners, thereby changing how the industry overall carries out the value-adding processes.

Business scope redefinition - extending the market or creating new products, based on information, or changing the role of the organization in the industry, such as with the introduction of a new information-enabled business model.

IT Paradigms: Nilsson (1995) identifies six paradigms in IT research:1- Systems view: developed in the mid-1960s. This paradigm focuses on IT as a system with components that accomplished tasks in a natural and logical order (i.e. top-down and bottom-up). 2-the Socio-technical view: developed in the early 1970s, and focuses on the interaction between people and computers. This paradigm has been influenced by organization and psychology theories. 3- The political view: was developed in the mid-1970s and focuses on IT as a force that participates in a change process.4The actor-based view: was developed in the early 1980s and focuses on persons or individuals as the focus for IT work. 5-the network approach: was developed in the mid-1980s and focuses on the relationships between actors' networks which other actors' networks and 6- The multilevel approach: focuses on IT in terms of levels such as, logical levels, i.e. persons, business infrastructure, information operations and environment, structural levels, i.e. information infrastructure, and other levels.

\section{Management science (MS)}

Management Science (MS) started in 1953 (Hopp, 2004 , p. 6), with the establishment of The Institute of Management Sciences (TIMS) (Hopp2004, p. 1). The discipline of MS is also known as Decision Science (DS), Operational Research (OR), and Success Science (SS) Arsham (2005, Hopp, 2004). MS research is influenced by other disciplines: Accounting and finance, Business strategy, Decision Analysis, Information systems, Manufacturing and distribution, Marketing, Mathematical Programming and Networks, Organization Performance, Public Sector Applications, R\&D or Innovation, Stochastic Models and Simulation, Strategy and Design, Supply Chain Management (Arsham, 2005, p. 7). Although MS research covers many issues, its focus lies on strategic planning. Strategic decision making approaches in MS Research: Strategy is considered an outcome of planned as well as emergent strategic decision making (Hill and Jones, 1998). The strategic management paradigm sees strategy as formulated and implemented through a centralized strategic planning approach based on rational analysis (Schendel and Hofer, 1979). Strategy is also conceived as an emergent or decentralized approach where strategy is formed as a pattern of important organizational decisions (Mintzberg, 1978, 1994).

The strategic planning approach conceives strategy as a formal process by which top management establishes decision rules to guide and coordinate the organization's longer term actions (Lorange and Vancil, 1977; Ansoff, 1988). Schendel and Hofer (1979) outline the strategic management paradigm by incorporating a number of rational steps in a centralized strategy development process, e.g., goal formulation, competitive ananlysis, strategy formulation, evaluation, implementation and control. This approach is reflected in large parts of the strategy literature (Porter, 1980; Richards, 1986, Goold and Quinn, 1993)

The emergent or decentralized strategy approach is conceived as a political process managed by coalitions or organizational decision makers formed around emerging strategic issues (Narayanana and Fahey, 1982). It is also conceptualized as a social learning process, where managers can take actions based on experiences gained in different parts of the organization (Normann, 1985; Burgelman, 1988). Middle Managers' resource committing decisions develop the capabilities that eventually shape the firm's strategic aptions (Bower, 1982; Noda and Bower, 1996). Managers can often take independent actions that influence the firm's strategic development, so strategy can emerge even without the engagement of top management (Mintzberg, 1994). In other words, decentralized strategic decision making practices can involve managers through autonomy that allows them to take actions that have strategic consequences, and through their participation in the firm's important strategic decisions.

MS Paradigms: Several researchers (Mintzberg 1991, 1998, O'Shannassy 1999, and Whittington 2001), have analyzed the evolution of the strategic paradigm. While Mintzberg (1991) and Whittington (2001) classify strategy theories in relation to the development of strategies, O'Shannassy (1999) reviews the evolution of the strategic paradigms in relation to management. Since management paradigms are more related to SMIT, the results of O'Shannassy (1999) are briefly here.

O'Shannassy (1999) summarizes the evolution of strategic research in MS in five paradigms: basic financial planning, forecast-based planning, externally oriented planning, strategic management, and strategic thinking paradigm. 
Basic financial planning: The first paradigm, it started in 1950. The planning focus is related to the financial budget with a time horizon slightly beyond 12 months. Some of the researchers that can be included within this paradigm are Drucker (1954), and Selznic (1957).

Forecast-based planning: it started in 1960 as organizations started to embrace a longer time horizon, environmental analysis, multiyear forecasting and static factor allocation. Researchers that belong to this paradigm are Chandler (1962), Ansoff (1965), Andrews78 (1980).

Externally oriented planning, it started in 1970 meaning that strategic planning includes situation analysis, a review of competition, and an evaluation of alternative strategies and dynamic factor allocation. This paradigm produced many frameworks such as: the Experience Curve, the Boston Consulting Group's (BCG) portfolio matrix, and the Profit Impact of Marketing Strategies (PIMS) empirical project O'Shannassy, 1999, pp. 5-7).

Strategic management: it started in 1980. It focuses on the combination of a business organization's factors to achieve competitive advantages. This paradigm includes three factors: a planning framework, a planning process and corporate visions and values. Important contributions to this phase include contributions from other disciplines. For example Porter (1980, $1985,1990)$ contributed with the integrated the structure - conduct - performance theory in industrial - organization economics. He also created frameworks such as five forces, the value chain, and the diamond model of competitive advantages. Another contribution grounded in field economics are the contributions of Wernerfelt (1984), Barney (1991), and Peteraf (1993).

\section{Strategic thinking}

It started in the mid-1980s. IT initiates the process of developing new strategic solutions that are not included in existent strategic frameworks. Contributors to this phase are Ohmae (1982), Stacey (1993), and Cummings (2003).

The relation between Strategic management and competitive environment: Competition is a continuous learning process, where strategies need to be continually adjusted in order to achieve competitive advantages.

Three factors relate to MS and affect competitive outcomes the most: 1) The role of the strategic manager in competition. 2) The role of the competitive environment. And 3) The role of theories of competition. competitive advantages

Industry competition? an industry is a group/collection of firms offering products or services that are close substitutes for one another (Porter, 1980; Pearce and Robinson, 2005). Individual industries may differ from each other according to the degree of competition among various buyers and sellers in each market (Lipsey, 1987). According to Porter (2008), industry structure grows out of a set of economic and technical characteristics that determine the strength of competitive forces in an industry. Porter says that industry structure drives competition and profitability. The degree of competitiveness of the market structure refers to the degree to which individual firms have power over that market- power to influence the price or other terms on which their product is sold. Factors that have been used to classify industries because they influence behaviors and therefore performance of firms include the number of sellers; the degree of product differentiation; presence or absence of entry, mobility, exit, and shrinkage barriers. Others are cost structure, degree of vertical integration, and degree of globalization (Lipsey, 1987; Kotler, 1998; Porter, 1980; Pearce and Robinson, 2005). These market characteristics give rise to four known industry structure types namely, pure monopoly, oligopoly, monopolistic competition, and perfect competition Porter (1980) developed the Five Force industry analysis Model, which has a theory that there are five forces that determine competition in an industry. These forces form the basic characteristics of competition in an industry. Hence the strongest competitive force determines the profitability of an industry and its importance in strategy formulation. By far, the Five Forces Model, which forms the basis of this study, is the most influential and widely used framework for evaluating industry attractiveness. Essentially, Porter (1980) postulates that there are five forces that typically shape the industry structure: intensity of rivalry among competitors, threat of new entrants, threat of substitutes, bargaining power of buyers, and bargaining power of suppliers. The five competitive forces reflect the fact the competition in an industry goes well beyond the established players. All the five forces jointly determine the intensity of industry competition and profitability, and the strongest force or forces are governing and become crucial from the point of view of strategy formulation. To establish the strategic agenda for dealing with these contending forces and to grow despite them, a company must understand how they work in the industry and how they affect the company in its particular situation (Pearce and Robinson, 1997).

Porter (1979) first presented a succinct and lucid view of the factors shaping competition. Porter views an industry as consisting of: firms jockeying for preferred positions while being impact by the bargaining power of suppliers, the bargaining power of customers, the threat of new entrants, and the threat of substitute products or services. These forces, affecting all 
competitors must be contented with strategically by the firm if it is to go grow and prosper. Porter suggests that companies need to address strategic action based on the factors identified in the model. These actions consist of diminishing customer or supplier power, lowering the threat of substitute products entering the market place, discouraging new entrants, or gaining competitive edge within the existing industry.

Competitive advantage: Competitive advantage is a possible competitive outcome. Competitive advantages represent a possible outcome of the competitive process. The achievement of competitive advantages is one primary role of strategic management. By focusing in the achievement of competitive advantages, during the process of strategic analysis, strategic managers may combine strategies in ways that may affect the competitive environment. Competitive advantages may not always be the traditional outcome of a competitive goal, because many factors related to strategic management are complex. However, competitive advantages can be considered as a major goal for using strategies. Porter (1985a) defines competitive advantage as: "Competitive advantage is the ability to earn returns on investment persistently above the average for the industry". (Porter, 1985a)

Competitive advantage as it is used in this research refers to the desired goal of competition, and it is related to company strategies with the aim of gaining any form of advantage, for example, profit, or nonprofit. Porter (1980) identified two basic types of competitive advantage:

1) Cost advantage: A competitive advantage exists when the firm is able to deliver the same benefits as competitors but at a lower cost

Differentiation advantage: when the firm is able to deliver benefits that exceed those of competing products.

The role of strategic management in competition:
Strategic management is a key issue to enable competitive advantages. First, Johannsen \& Page (1986) relate the concept of strategic management to the consideration of environmental opportunities, which can be interpreted as competitive advantages. Alvesson \& Willmott (1996) consider strategic management as related to competition but also as the ability to combine strategic factors to cope with changes. While Turban et al. (2001), include others' roles in the definition of strategic management as predicting the future operations of the firm. The definition of Faulkner \& Campbell (2003a) points out that strategic management relates to two factors: competitive advantage and the management of change. Faulkner \& Campbell (2003a), introduce not only the term advantages as the main aim of strategic management, but also indicates that the circumstances that surround competition may change continuously strategic management activities are proactive or reactive activity, which tries to balance the characteristics of the competitive environment.

Factors that relate to strategic management and affect the competition: Strategic management deals with internal and external factors. Among the internal factors, one can consider other managers, business goals and competitive resources. Among the external factors (factors outside the boundaries of the business), one can consider the competitive environment, competitors' strategies and changes. Moreover, both internal and external factors can change over time, changing the premises of competition and making the strategic management task much more complex. The strategic manager has to consider the combination of internal and external factors to be able to achieve competitive advantages. However, these competitive factors may change over time and affect the strategic manager's choices for competition.

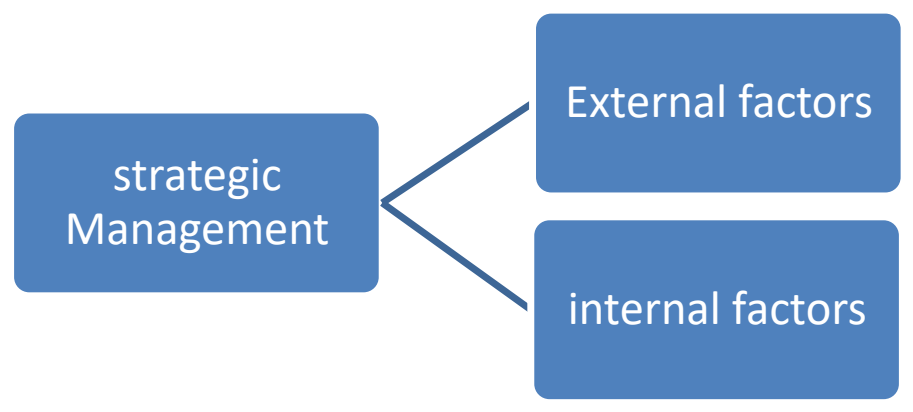


The role of strategic management in competition can be summarized as: 1) Identification of the future competitive environment (Cardullo (1996, p. 46), Faulkner et al. (2003, p. 3), Turban et al. (2001, p. 77). 2) Identification and development of competitive strategies (Faulkner et al. (2003, p. 3), Turban et al. (2001, p. 77). 3) Identification of competitive factors Cardullo (1996, p. 46), Turban et al. (2001, p. 77). 4) Management change (Faulkner et al. (2003, p. 3), Turban et al. (2001, p. 77) and 5) Achievement of strategic alignment (Mintzberg et al. (1991, p. 5).

Identification of the future competitive environment: In order to predict the future competitive environment, it is important to understand the time related to changes. Pitkethly (2003, p. 243) also supports this argument when he says, "Understanding the rate of change in the environment is thus just as important as understanding what changes are occurring." The consideration of time is important for competition, because being too late or too early with a competitive strategy may affect the benefits of the advantage. Considering time in the prediction means that trends may change over time, making the prediction a dynamic factor that relates to the dynamic factors of strategy. Consequently, in order to use strategic management as a tool to influence the outcomes of competition, a continuous prediction of the future competitive environment should be done.

Identification and development of competitive strategies: The identification of competitive strategies is related to the competitive environment. Once the environment has been identified, it is time to identify a way to compete in that environment. A way of competing in the environment may be described by the combination of business strategies to compete in the specific market, and a way to identify and manage competitive factors.

\section{Identification of competitive factors:}

\section{A- Management of change}

Management of change is related to response activities aimed to cope with competitors' actions in the competitive arena. The need to manage change became clear during the 1990s, not only due to changes in the competitive environment, but also due to changes in information technology. The fast development of IT as technology and its impact on competition makes change an important factor to analyze in order to achieve competitive advantages in the future.

\section{B- Achievement of strategic alignment}

Strategic alignment is about the achievement of fit or congruence between strategies. Porter (1996), defines Strategic alignment as all the strategies used within a company must harmonize, be consistent, and support each other at all organizational levels in order to produce results. Most researchers agree that strategic alignment is required to achieve competitive advantages. This is because companies may require a combination of several competitive strategies that may use the same competitive factors, for example, money, people, and systems. Consequently, in order to achieve competitive advantages alignment between different strategies is needed to produce results. (Buxbaum, 2001).

\section{Factors related to strategic management}

The strategic management role of the identification of the future competitive environment, applied to the factor competitive environment, the identification and development of competitive strategies applied to the factor competitive strategy, the identification of competitive factors applied to competitive factors. However, the role of management change, and achievement of strategic alignment did not specify any factor at all. Analyzing the implications of these open roles, one can conclude that they should apply to common strategic factors. It was observed that the same role 'identification' applied to all factors, i.e. competitive environment, competitive strategies, competitive factors. Considering that these different factors relate to the same role, i.e. identification, this thesis assumes that these factors are to be considered as common factors for strategic management. Consequently, the roles of management change and strategic alignment should also apply to those common strategic factors.so, the roles related to strategic management are selection and evaluation, the management of change and strategic alignment. The strategic factors related to strategic management are the competitive environment, competitive strategies and competitive factors.

Relation between competitive environment, competitive strategy, and competitive factors.

Analyzing the effects of the competitive environment into competitive factors one can say that during the last 20 years the evolution of the competitive environment has changed the characteristics of competitive factors. This phenomenon has been addressed by Drucker (1994) who writes,"the importance of productive factors (land, capital, and work) will diminish while the importance of expertise and knowledge will increase." In the knowledge society, global leading industries improve productivity by being more innovative, values effectiveness as a continuous learning process and measures competitiveness as the level of workforce's knowledge. The identification of the competitive environment is required prior to a selection of competitive factors. This is because competitive environment values competitive factors differently. Consequently, competitive factors are only effective in enhancing competitive advantages in specific competitive 
environments For instance; the value of the same competitive factors may vary depending if they are used in an industry or a business environment. Moreover, in order to enhance competitive advantages, competitive factors be exploited and integrated into a firm, and imitating competitors must be avoided.

Identification of competitive factors: The Value Chain Model developed by Porter (1985a, p. 33-61) is used to identify competitive factors in the business environment. According to this model, every firm's value chain is composed of nine generic activities linked to each other and to the activities of its suppliers, channels, and buyers.

There are two types of activities; primary activities, which involve the physical creation of the product, its sale and transfer to the buyer, and after sales service; and support activities, which support the primary activities by providing purchased inputs, technology, human factors, and various firm-wide functions. To diagnose a firm's competitive advantage, it is necessary to isolate activities with discrete technologies and economics. However, in the case of information technology, with the uses of integrated systems, for example, ERP, the isolation of discrete activities may be possible, but the valuation of intangible factors due to the integrated system may be difficult to evaluate.

IT is a competitive factor: IT is a competitive factor because the developments of IT and the Internet have made possible data processing between customers, companies, and markets. Additionally, IT solves problems related to the delivery of information, lower transactions cost, fast availability in time, regardless of geographic distance, which enhances the possibility of achieving competitive advantages. The influences of IT on the competitive environment have been analyzed by Porter \& Millar (1985, p. 150) in three major characteristics. One characteristic is that IT changes the rules of competition. Another characteristic is that IT allows lower costs, enhances differentiation, and changes the competitive scope. A third characteristic is that IT allows the creation of new businesses within old ones. In the Capodagly et al, (2001) definition of the competitive environment new economy. They identify competitive factors that are in alignment with the new economy into three areas: business, technology, and social. Related to technological factors Capodagly (2001) considers mobile, fixed, and wireless technologies; the Internet, intranets, extranets; IP telephony; voice, data video convergence; and distributed networking. In other words, technologies behind the Internet, network and wireless, would not be useful in competing in the "new economy." On the other hand, IT developments that present better functionality could also become competitive factors. Having given an example about the need to match competitive environment and competitive factors, the next section explores characteristics of IT that are important to consider in strategic analysis.

\section{IT Characteristics}

IT to consider in strategic analysis is IT characteristics.' Considering the gaps found in prior research it is important to determine the competitive characteristics of IT. The analysis of IT characteristics of IT is important from a business point of view for several reasons. One reason is to enhance communication by reducing the confusion that many people have regarding technology210. Another reason is to improve the understanding of IT management by exploring benefits and risks related to IT as a competitive factor. An additional reason is to improve the level of strategic alignment by improving managers' understanding of the language and processes of IT in organizations 211. Additionally, the results of the analysis of the characteristics of IT can be used to communicate a common understanding of IT, between business and IT managers. The next section analyzes this category in order to identify relevant areas of analysis. Analyzing the data focusing on the characteristics of IT, two types of factors were found, static and dynamic characteristics. Static characteristics are those characteristics of IT that change at a slow pace and seem to be stable, for example, technological characteristics. Dynamic characteristics are those that change at a fast pace, for example, technological developments, and technology prices. In order to understand the rationale behind static and dynamic characteristics, they will be briefly introduced in this section.

Static characteristics: Static characteristics are related to IT characteristics that may be considered as relatively stable or with little change. According to this static view the characteristics do not change at all or change so little that one can consider the characteristics with constant values. Examples of static characteristics can be definitions, IT components, and competitive factors of IT. A definition of IT is used in the strategic analysis to explain the meaning of IT and to create a common understanding of IT as a competitive factor. The meaning of IT can be described in terms of the etymology and origin of the word, explaining the processes involved with IT. The components of IT, analyze and describe the components of IT, and also explain how the parts fit together. This characteristic contributes to creating a common understanding of IT. The competitive characteristics are characteristics of IT that affect competition. Since MIS research mostly focuses on characteristics of IT that enhance competition, i.e. low transactional cost, fast delivery, it is important to include characteristics that may restrain competition, for example, uncertainties. This is important because in order to manage IT effectively, it is 
necessary to understand factors that may restrain the effects of IT in competition.

Dynamic characteristics: The dynamic characteristics relate to change and the dynamic part of strategic management. This category includes dynamic characteristics of IT changes in which may affect competition, for example, changes in technology scope, functionality, price, and availability. It is important include this characteristic in the analysis because much IT research considers only static factors of IT and excludes the analysis of IT changes, denying the evolution of the technology. However, the consideration of IT developments is important for strategic analysis, since these developments affect not only industrial processes, but also competition, and markets. This is a challenge for strategic management for several reasons. One reason is that it makes difficult the formulation of long-term strategies for IT. Another reason that challenges the strategic management of IT is the difficulty to predict the impact of new IT developments on the competitive environment. This is because new IT developments may increase the use of IT in business, which might affect the competitiveness of the firm. Having given an introduction about characteristic of IT as a competitive factor, the next section introduces another characteristic for the analysis of IT as a competitive factor called complementaries.

Complementaries: Focusing on the fact that IT alone does not achieve competitive advantages, another characteristic to include in strategic analysis is 'Complementaries'. This category considers resources outside IT that are needed to assure or increase the impact of IT on competition. Complementaries may enhance or restrain the impact of IT. This category is designed to include two types of complementaries 'internalities,' and 'externalities.'

Internalities: Internalities refer to characteristics outside IT that can be found in the organization and which strategic management may control or influence. Examples of internalities may be data skills training, knowledge sharing, information sharing, and capabilities.

Externalities: Externalities refer to characteristics outside IT that are beyond the influence of strategic managers. Some externalities may increase the impact of IT, for example, network externalities, industry infrastructure. Other externalities may limit the impact of IT, for example, changes in the competitive environment, global conjuncture.

Competitive effect: Competitive effect relates to characteristics that can indicate the level of impact of IT. For instance, some examples of competitive effect characteristics are micro and macro effects. While an example of micro effect focuses on the quick delivery of information within an organization, a macro effect would focus on the delivery of information to the industry or the globe.

\begin{tabular}{|c|c|c|}
\hline \multicolumn{3}{|c|}{ IT as Competitive Factor } \\
\hline IT characteristics & Complementaries & Competitive Impact \\
\hline (Factors related to IT as factor) & (Factors outside of IT) & $\begin{array}{l}\text { Micro effects } \\
\text { Effects within the organization }\end{array}$ \\
\hline $\begin{array}{l}\text { Static factors } \\
\text { IT factors } \\
\text { Competitive factors } \\
\text { Certainties } \\
\text { Uncertainties }\end{array}$ & $\begin{array}{l}\text { Internalities } \\
\text { People skills } \\
\text { Capabilities } \\
\text { Knowledge Sharing } \\
\text { Internal alignment } \\
\text { Technology uses } \\
\end{array}$ & $\begin{array}{l}\text { Macro effects } \\
\text { Effects outside the organization }\end{array}$ \\
\hline $\begin{array}{l}\text { Dynamic Factors } \\
\text { Changes in Technology } \\
\text { Changes in Technology prices } \\
\text { Changes in Technology } \\
\text { availabilities }\end{array}$ & $\begin{array}{l}\text { Externalities } \\
\text { Network externalities } \\
\text { National infrastructure } \\
\text { Changes in the Competitive } \\
\text { Environment }\end{array}$ & \\
\hline
\end{tabular}




\section{The Framework}

The factors considered in this framework can be summarized in three major factors: Competitive
Environment, Competitive Outcome, and Strategic Management.

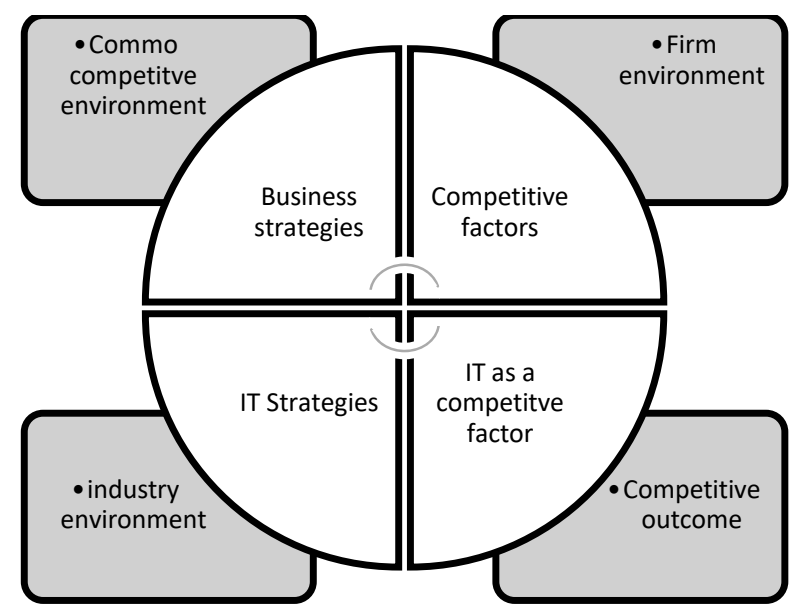

Strategic Technology Management (STM) Framework.

\section{Factors related to STM:}

1) Macro factors: those that are outside the boundaries of the firm such as

a) Competitive environment

2) Micro factors: those that are within the boundaries of the firm such as:

a) Strategic management.

b) Competitive strategies.

c) Competitive factors.

\section{Research Design}

The methods used in this research to obtain the data for abductive reasoning was a questionnaire, results of which were analyzed to evolve the framework. The logic of how the empirical data is connected to the proposition is based on comparing and matching of the developed initial framework with the results of the conducted interviews in STMs. It was expected that STMs are strategically focused enterprises and concentrating on the most essential activities for the company's success, so findings on technology management activities among STMs would reveal the most important ones. Consequently, information is gathered from multiple sources and to find the best possible description for the elements in the framework. It is expected that the results support the contents of the initial framework, thus increasing its validity.

\section{Sample of the study}

The empirical study was carried out in 18 Small to Medium-sized Enterprises in Kuwait in Dasman area in the summer of 2017. Due to practical reasons, but compliant to requirements of qualitative research (see Yin, 2003), the geographical scope was limited to enterprises having premises and personnel in the Dasman area, to ensure availability of the interviewees, and for efficient use of the research resources. The sample of the interviewed companies has global market, customers, competition and operations. The companies are designing, manufacturing and providing electronics, mechanical, medical instruments and software products, solutions and services. The criteria for selecting the sample were companies' exposure to high-technology business environment. The 25 interviewees were persons responsible on functions dealing with the topics of technology management i.e. business, product, technology and R\&D management, typically company founders and senior managers of the companies. Working experience of the interviewees was between 15 to 25 years. The structural questionnaire (Appendix 1 and 2) consisted of 12 open qualitative questions and 18 closed questions to be quantitatively evaluated by the interviewees. Due practical reasons the number of questions was reduced from a total of 48 to 30 , after running a test interview. The instrument used in this research was the relative scale from 1 to 5 for evaluating importance and current state of the practice. 


\section{Search community and search sample:}

This study is cross sectional in nature where by a sample of 20 managers of companies was randomly taken from the population of managers of companies. The questionnaires, with instructions of how to complete them, were distributed to respondents by an interviewer. After completion, the questionnaires were checked and collected by the interviewer. However, due to some invalid questionnaires which were removed from the sample. The total sample size was 18 .

\section{Statistical techniques}

SPSS program by using descriptive statistics, Person correlation, Cronbach's Alpha and factor analysis used to analysis the data.

\section{Characteristics of the research sample:}

The frequencies and percentages of the sample were calculated according to the variables (Gender - Age Education - Experience)

Distribution of sample members by gender :

Table (3-1) Distribution of sample members by gender

\begin{tabular}{|l|l|l|}
\hline Gender & Frequency & Percent \\
\hline male & 10 & $55.6 \%$ \\
\hline female & 8 & $44.4 \%$ \\
\hline
\end{tabular}

From the above table we conclude that the research sample was divided into two categories in terms of gender to (male) with percentage $(55.6 \%)$ and the category (female) with percentage $(44.4 \%)$.

Distribution of sample members by age :

Table(3-2) Distribution of sample members by age

\begin{tabular}{|l|l|l|}
\hline Age & Frequency & Percent \\
\hline less than 30 years & 4 & $22.2 \%$ \\
\hline $\begin{array}{l}\text { between 30 years and 40 } \\
\text { years }\end{array}$ & 7 & $38.9 \%$ \\
\hline more than 40 years & 7 & $38.9 \%$ \\
\hline
\end{tabular}

From the above table we conclude that The research sample was divided into categories in terms of age to(less than 30 years) with percentage $(22.2 \%)$, the category (between 30 years and 40 years) with percentage (38.9\%) and the category (more than 40 years) with percentage $(38.9 \%)$.

Distribution of sample members by Education :
Table (3-3) Distribution of sample members by Education

\begin{tabular}{|l|l|l|}
\hline Education & Frequency & Percent \\
\hline Certificate & 6 & $33.3 \%$ \\
\hline Diploma & 7 & $38.9 \%$ \\
\hline Undergraduate & 3 & $16.7 \%$ \\
\hline Post Graduate & 2 & $11.1 \%$ \\
\hline
\end{tabular}

From the above table we conclude that The research sample was divided into categories in terms of Education to(Certificate) with percentage $(33.3 \%)$, the category (Diploma) with percentage $(38.9 \%)$, the category (Undergraduate) with percentage $(16.7 \%)$ and the category (Post Graduate) with percentage (11.1\%).

\section{Distribution of sample members by Experience}

Table(3-4) Distribution of sample members by Experience

\begin{tabular}{|l|l|l|}
\hline Experience & Frequency & Percent \\
\hline Less than 3 years & 2 & $11.1 \%$ \\
\hline From 3 to 5 years & 7 & $38.9 \%$ \\
\hline More than 5 years & 9 & $50 \%$ \\
\hline
\end{tabular}

From the above table we conclude that The research sample was divided into categories in terms of Experience to (Less than 3 years) with percentage (11.1\%), the category (From 3 to 5 years) with percentage $(38.9 \%)$ and the category (More than 5 years) with percentage $(50 \%)$.

\section{Search Tool:}

After reviewing the previous studies related to the subject of the research, a questionnaire was prepared to study A Framework for the Strategic Management of Information Technology. I depended on the questionnaire as an essential tool for collecting the data needed to support theoretical research in the practical side to answer the research questions and achieving its objectives. The questionnaire was designed by looking at some of the tools and measures of other studies relevant to the current research topic ،

The questionnaire contains a set of phrases that support the research topic through its direct relationship with the research objectives and questions.

The questionnaire contained two main parts:

The first part: consists of demographic data on the research sample. 
The second part: consists of the study axes

The first axis: contains of 10 Phrases

The second axis: contains of 10 Phrases

The third axis: contains of 10 Phrases

The fourth axis: contains of 10 Phrases

To answer these phrases we used fifth Likert scale with degrees from 1 to 5

\section{The reality of search tool}

Virtual reality : After completion of the preparation of the questionnaire and the construction of paragraphs c and presented to the supervisor of the research was presented in the initial questionnaire in the form of a group of professors

In order to ascertain the extent to which each paragraph is related to the axis to which it belongs And the clarity and integrity of the formulation of phrases Until the questionnaire became in its final form contains of 4 axis and (40) phrases

Validate the internal consistency of the search tool:

The validity of the internal consistency of the study axes:

We calculated internal consistency by calculated Pearson correlation coefficient between the each phrase and the axis that belonged it as shown in next table :

\section{Table (3-5)}

\begin{tabular}{|c|c|}
\hline number of phrase & correlation coefficient \\
\hline \multicolumn{2}{|l|}{ The first axis } \\
\hline 1 & $.891 * *$ \\
\hline 2 & $.860 * *$ \\
\hline 3 & $.892 * *$ \\
\hline 4 & $.956 * *$ \\
\hline 5 & $.950 * *$ \\
\hline 6 & $.965 * *$ \\
\hline 7 & $.993 * *$ \\
\hline 8 & $.965 * *$ \\
\hline 9 & $.932 * *$ \\
\hline 10 & $.993 * *$ \\
\hline \multicolumn{2}{|l|}{ The second axis } \\
\hline 1 & $.857 * *$ \\
\hline 2 & $.599 * *$ \\
\hline 3 & $.893 * *$ \\
\hline 4 & $.928 * *$ \\
\hline 5 & $.901 * *$ \\
\hline 6 & $.922 * *$ \\
\hline 7 & $.937 * *$ \\
\hline 8 & $.922 * *$ \\
\hline 9 & $.882 * *$ \\
\hline 10 & $.718 * *$ \\
\hline
\end{tabular}

\begin{tabular}{|l|l|}
$\mid$ The third axis \\
\hline 1 & $.956^{* *}$ \\
\hline 2 & $.962 * *$ \\
\hline 3 & $.990^{* *}$ \\
\hline 4 & $.962^{* *}$ \\
\hline 5 & $.929^{*}$ \\
\hline 6 & $.990^{* *}$ \\
\hline 7 & $.859^{* *}$ \\
\hline 8 & $.601 * *$ \\
\hline 9 & $.897 * *$ \\
\hline 10 & $.913^{* *}$ \\
\hline The fourth axis & \multicolumn{1}{|l|}{} \\
\hline 1 & $.933^{* *}$ \\
\hline 2 & $.750^{* *}$ \\
\hline 3 & $.856^{* *}$ \\
\hline 4 & $.957 * *$ \\
\hline 5 & $.956^{* *}$ \\
\hline 6 & $.945^{* *}$ \\
\hline 7 & $.976^{* *}$ \\
\hline 8 & $.945^{* *}$ \\
\hline 9 & $.919^{* *}$ \\
\hline 10 & $.782^{* *}$ \\
\hline$*$ Correlation is significant at the 0.01 level (2-tailed).
\end{tabular}

From the above table we conclude that all Pearson correlation coefficients between the each phrase and the axis that belonged it come with high degree and significant at (0.01) which indicates a high degree of validity of the internal consistency of the terms of the questionnaire axes.

Internal consistency between the axes of the questionnaire. The study calculated internal consistency by calculated Pearson correlation coefficient between each axis and the total degree of questionnaire as following in the following table

Table (3-6) Pearson correlation coefficient between the each axis and the total degree of questionnaire

\begin{tabular}{|l|l|}
\hline Axis & Total degree \\
\hline The first axis & $.984^{* *}$ \\
\hline The second axis & $.990^{* *}$ \\
\hline The third axis & $.990^{* *}$ \\
\hline The fourth axis & $.982^{* *}$ \\
\hline
\end{tabular}

**Correlation is significant at the 0.01 level (2-tailed).

From the above table we conclude that all Pearson correlation coefficients between the each axis and the total degree of questionnaire with high degree and significant at (0.01) which indicates a high degree of Internal consistency between the axes of the questionnaire. 


\section{Reliability of questionnaire:}

To ensure of the reliability of questionnaire we used Cronbach's Alpha test as shown in the following table

Table (3-7)Cronbach's Alpha coefficients

\begin{tabular}{|l|l|l|}
\hline axis & Cronbach's Alpha & N of Items \\
\hline The first axis & .985 & 10 \\
\hline The second axis & .958 & 10 \\
\hline The third axis & .975 & 10 \\
\hline The fourth axis & .974 & 10 \\
\hline The total degree & .993 & 40 \\
\hline
\end{tabular}

From the above table we conclude that the reality coefficients value of the all axis of questionnaire was all of high scores approaching the correct one and the total degree of reality was (.993) which is high value and approaching the correct one and it refers to The validity of the questionnaire for the application and the reliability of its results.

\section{Results and discussion}

The first axis: The means, standard deviation calculated in the following table

Table (4-1)the means and standard deviation for the first axis

\begin{tabular}{|l|l|l|l|l|}
\hline No & Phrase & Mean & Std. Deviation & Opinion \\
\hline 1 & Strategic management deals with internal and external factors & 4.17 & .786 & Agree \\
\hline 2 & $\begin{array}{l}\text { one can consider other managers, business goals and competitive re- } \\
\text { sources }\end{array}$ & 4.17 & .618 & Agree \\
\hline 3 & $\begin{array}{l}\text { both internal and external factors can change over time, changing the } \\
\text { premises of competition and making the strategic management task } \\
\text { much more complex }\end{array}$ & 4.22 & .878 & strongly agree \\
\hline 4 & $\begin{array}{l}\text { The strategic manager has to consider the combination of internal } \\
\text { and external factors to be able to achieve competitive advantages. }\end{array}$ & 4.00 & .840 & Agree \\
\hline 5 & $\begin{array}{l}\text { the competitive factors may change over time and affect the strategic } \\
\text { manager's choices for competition }\end{array}$ & 3.89 & .832 & Agree \\
\hline 6 & $\begin{array}{l}\text { The strength of institutional control contributes to the continuity of } \\
\text { the organization and its avoidance in crises }\end{array}$ & 4.00 & .840 & Agree \\
\hline 7 & Pay attention to values of information and communication systems & 3.94 & .802 & Agree \\
\hline 8 & $\begin{array}{l}\text { Availability of clear legislation related to investment, taxation and } \\
\text { customs }\end{array}$ & 4.00 & .840 & Agree \\
\hline 9 & $\begin{array}{l}\text { The availability of international or local accounting and auditing } \\
\text { standards. }\end{array}$ & 3.83 & .924 & Agree \\
\hline 10 & $\begin{array}{l}\text { Keeping up with the speed of technical development in the field of } \\
\text { work. }\end{array}$ & 3.94 & .802 & Agree \\
\hline Total Degree & 4.02 & 0.82 & \\
\hline
\end{tabular}

From the above table we conclude that the managers of companies agree to the existence of strategic management with mean (4.02) and standard deviation (0.82). All phrases get the (5 and 4 ) degree of approval (strongly agree and agree ) with arrangement

- both internal and external factors can change over time, changing the premises of competition and making the strategic management task much more complex

- Strategic management deals with internal and external factors

- one can consider other managers, business goals and competitive resources

- The strategic manager has to consider the combination of internal and external factors to be able to achieve competitive advantages.
- The strength of institutional control contributes to the continuity of the organization and its avoidance in crises

- Availability of clear legislation related to investment, taxation and customs

- Pay attention to values of information and communication systems

- Keeping up with the speed of technical development in the field of work.

- the competitive factors may change over time and affect the strategic manager's choices for competition

- The availability of international or local accounting and auditing standards.

And we also conclude that the standard deviation for all phrases with small value which refers to 
Homogeneity of the opinions of the members of the research sample on the strategic management in the company
The second axis: We calculate the means, standard deviation and find the opinion as the following table

Table (4-2). Means and standard deviation for the second axis.

\begin{tabular}{|l|l|l|l|l|}
\hline No & Phrase & Mean & Std. Deviation & Opinion \\
\hline 1 & $\begin{array}{l}\text { The use of the computer in general in the company has the first role in } \\
\text { reaching technological innovations }\end{array}$ & 4.28 & .826 & strongly agree \\
\hline 2 & $\begin{array}{l}\text { Cooperation with scientific academic institutions helps in the develop- } \\
\text { ment of technological innovation }\end{array}$ & 3.94 & .873 & Agree \\
\hline 3 & $\begin{array}{l}\text { The technical databases adopted by the establishment are an essential } \\
\text { element in their success in technological innovation }\end{array}$ & 4.22 & .878 & strongly agree \\
\hline 4 & $\begin{array}{l}\text { Increasing the number of technicians specialized in research and devel- } \\
\text { opment leads to increased technological innovation }\end{array}$ & 4.11 & Agree \\
\hline 5 & $\begin{array}{l}\text { The participation of individuals in training programs and scientific con- } \\
\text { ferences has been a major cause of technological innovation }\end{array}$ & 4.06 & .873 & Agree \\
\hline 6 & $\begin{array}{l}\text { Cooperation with the scientific advisory bodies and organizations related } \\
\text { to the company's industry is a clear contribution to our technological in- } \\
\text { novation }\end{array}$ & 4.17 & .857 & Agree \\
\hline 7 & $\begin{array}{l}\text { The abundance of information needed to accomplish research and devel- } \\
\text { opment projects in quantity, timing and the appropriate type leads to } \\
\text { technological innovation in the establishment }\end{array}$ & 4.11 & .832 & Agree \\
\hline 8 & $\begin{array}{l}\text { The existence of channels of information exchange inside and outside } \\
\text { the facility has a great impact on technological innovation. }\end{array}$ & 4.17 & .857 & Agree \\
\hline 9 & $\begin{array}{l}\text { The existence of prior control and feedback of information contributes } \\
\text { to technological innovation }\end{array}$ & 3.89 & .963 & Agree \\
\hline 10 & $\begin{array}{l}\text { The Internet and the various sites where our facilities have helped us in. } \\
\text { Develop our technological innovation }\end{array}$ & 3.78 & 1.003 & Agree \\
\hline Total Degree & 4.07 & 0.88 & Agree \\
\hline
\end{tabular}

From the above table we conclude that the degree of manager' satisfaction in existence of technology management with degree (agree) with mean (4.07) and standard deviation $(0.088)$ which means that the research sample The existence of technology management

We found all phrases get the (4) degree of approval (agree) with except the phrases $(1,3)$ get $(5)$ degree of approval (strongly agree) arrangement:

- The use of the computer in general in the company has the first role in reaching technological innovations

- The technical databases adopted by the establishment are an essential element in their success in technological innovation

- Cooperation with the scientific advisory bodies and organizations related to the company's industry is a clear contribution to our technological innovation

- The existence of channels of information exchange inside and outside the facility has a great impact on technological innovation.
- Increasing the number of technicians specialized in research and development leads to increased technological innovation

- The abundance of information needed to accomplish research and development projects in quantity, timing and the appropriate type leads to technological innovation in the establishment

- The participation of individuals in training programs and scientific conferences has been a major cause of technological innovation

- Cooperation with scientific academic institutions helps in the development of technological innovation

- The existence of prior control and feedback of information contributes to technological innovation

- The Internet and the various sites where our facilities have helped us in. Develop our technological innovation

And we also conclude that the standard for all phrases with small value which refers to Homogeneity of the 
opinions of the members of the research sample on the existence of technology management in the company except for the phrase (10) with large value which refers to the difference of opinions about this
The third axis: We calculate the means, standard deviation and find the opinion as the following table.

Table (4-3). the means and standard deviation for the third axis

\begin{tabular}{|l|l|l|l|l|}
\hline No & Phrase & Mean & Std. Deviation & Opinion \\
\hline 1 & The company can penetrate new markets & 3.89 & .832 & Agree \\
\hline 2 & The company is innovating new products & 4.00 & .840 & Agree \\
\hline 3 & The company presented more than one product & 3.94 & .802 & Agree \\
\hline 4 & $\begin{array}{l}\text { The company maintains its position in the local and foreign mar- } \\
\text { kets }\end{array}$ & 4.00 & .840 & Agree \\
\hline 5 & The company has obtained good manufacturing requirements & 3.83 & .924 & Agree \\
\hline 6 & The company seeks to reach strategic alliances within it & 3.94 & .802 & Agree \\
\hline 7 & The company is working to reduce cost rates & 4.28 & .826 & Agree \\
\hline 8 & The company seeks quality marks agree & strongly agree \\
\hline 9 & $\begin{array}{l}\text { There is diversity and renewal of the ways and methods of work at } \\
\text { the company }\end{array}$ & 4.22 & .873 & .878 \\
\hline 10 & The company promotes innovative behaviors & 4.11 & .832 & Agree \\
\hline Total Degree & 4.02 & 0.84 & Agree \\
\hline
\end{tabular}

From the above table we conclude that the degree of managers' opinion of Competitive environment of the company with degree (agree) with mean (4.02) and standard deviation (0.84) which means that the research sample Approval of the presence of Competitive environment of the company

We found the all phrases get the (4) degree of approval (agree) except the phrases $(7,9)$ get the $(5)$ degree of approval (strongly agree) with arrangement:

- The company is working to reduce cost rates

- There is diversity and renewal of the ways and methods of work at the company

- The company promotes innovative behaviors

- The company is innovating new products

- The company maintains its position in the local and foreign markets
- The company presented more than one product

- The company seeks to reach strategic alliances within it

- $\quad$ The company seeks quality marks

- The company can penetrate new markets

- $\quad$ The company has obtained good manufacturing requirements

And we also conclude that the standard deviation for all phrases with small value which refers to Homogeneity of the opinions of the members of the research sample on the Competitive environment in the company

The fourth axis: We calculate the means, standard deviation and find the opinion as the following table 
Table (4-4)the means and standard deviation for the fourth axis

\begin{tabular}{|l|l|l|l|l|}
\hline No & Phrase & Mean & Std. Deviation & Opinion \\
\hline 1 & There are financial provisions for all fields of the company & 4.06 & .873 & Agree \\
\hline 2 & The company achieved high profits & 4.06 & .725 & Agree \\
\hline 3 & Employees receive high-value salaries & 4.28 & .895 & strongly agree \\
\hline 4 & Availability of funds in a timely manner & 4.06 & .802 & Agree \\
\hline 5 & $\begin{array}{l}\text { The company provides training and qualification opportunities for } \\
\text { employees at the expense of the company }\end{array}$ & 4.00 & .840 & Agree \\
\hline 6 & $\begin{array}{l}\text { It is noted that the productivity growth rates of the company's em- } \\
\text { ployees are high }\end{array}$ & 4.11 & .802 & Agree \\
\hline 7 & There is an increase in the value of exports to EU countries & 4.06 & .832 & Agree \\
\hline 8 & Relatively high exports to imports & 4.11 & .938 & Agree \\
\hline 9 & There is a growth in overall sales of the company & 3.94 & .900 & Agree \\
\hline 10 & $\begin{array}{l}\text { We note the growth of the market share in the local and foreign } \\
\text { markets }\end{array}$ & 3.89 & 4.06 & Agree \\
\hline \multicolumn{2}{|l|}{ Total Degree } & & Agree \\
\hline
\end{tabular}

From the above table we conclude that the degree of managers' opinion of Competitive profitability of the company with degree (agree) with mean (4.06) and standard deviation $(0.84)$ which means that the research sample Approval of the presence of Competitive profitability of the company

We found the all phrases get the (4) degree of approval (agree) except the phrase (3) get the (5) degree of approval (strongly agree) with arrangement:

- Employees receive high-value salaries

- It is noted that the productivity growth rates of the company's employees are high

- Relatively high exports to imports

- There are financial provisions for all fields of the company

- The company achieved high profits

- Availability of funds in a timely manner

- There is an increase in the value of exports to EU countries
- The company provides training and qualification opportunities for employees at the expense of the company

- There is a growth in overall sales of the company

- We note the growth of the market share in the local and foreign markets

And we also conclude that the standard deviation for all phrases with small value which refers to Homogeneity of the opinions of the members of the research sample on the Competitive profitability in the company

\section{The study hypotheses}

First, we must find the factors that achieves more competitive advantage

By using factor analysis and the results was shown as:

Table (4-5) the factors that achieves more competitive advantage

\begin{tabular}{|l|l|l|l|l|l|l|}
\hline \multicolumn{2}{|l|}{ Total Variance Explained } \\
\hline \multirow{2}{*}{$\begin{array}{l}\text { Compo- } \\
\text { nent }\end{array}$} & \multicolumn{2}{l|}{ Initial Eigenvalues } & \multicolumn{4}{l|}{ Extraction Sums of Squared Loadings } \\
\cline { 2 - 7 } & Total & $\%$ of Variance & Cumulative \% & Total & $\%$ of Variance & Cumulative \% \\
\hline 1 & .003 & .071 & 99.965 & 3.892 & 97.310 & 97.310 \\
\hline 2 & .103 & 2.584 & 99.894 & & & \\
\hline 3 & 3.892 & 97.310 & 97.310 & & & \\
\hline 4 & .001 & .035 & 100.000 & & & \\
\hline
\end{tabular}


From the above table we conclude that the highest degree of Explanatory variance is to first factor (strategic management) with value $(99.965 \%)$ then the second factor (technology management) with value $(99.894 \%)$

Table (4-6) The most saturated factors

\begin{tabular}{|l|l|}
\hline Component Matrix & \\
\hline & Component \\
\hline strategic management & 1 \\
\hline technology management & .989 \\
\hline Competitive environment of the company & .990 \\
\hline Competitive profitability of the company & .984 \\
\hline
\end{tabular}

From the above table we conclude that The highest saturation factors is technology management with degree (.990) then (strategic management) with degree (.989). So we can conclude that (strategic management and technology management) are the most factors that achieves more competitive advantage. Second we find the relation between the most two factors that achieves more competitive advantage(strategic management $\&$ technology management) by using person correlation and the results was shown as:

Table (4-7) relation between the most two factors that achieves more competitive advantage

\begin{tabular}{|l|l|l|}
\hline & & technology management \\
\hline \multirow{2}{*}{ strategic management } & Pearson Correlation & $.951 * *$ \\
\cline { 2 - 3 } & Sig. (2-tailed) & .000 \\
\hline
\end{tabular}

From the above table we conclude that there is significant relation between (strategic management $\&$ technology management) with degree (.951) more than $(0.5)$ and significant value (.000) less than (0.05) so we conclude that there is a strong significant correlation between the two factors (strategic management \& technology management)

Summary of results and recommendations Introduction:

After we get the results and presented it in the previous chapter we will introduce the summary of results and the recommendation

First: the summary of results

We present the most important results of the research and we arrived to:

- the managers of companies agree to the existence of strategic management with mean (4.02) and standard deviation (0.82)

- The degree of manager' satisfaction in existence of technology management with degree(agree) with mean (4.07) and standard deviation (0.088) which means that the research sample The existence of technology management
- The degree of managers' opinion of Competitive environment of the company with degree(agree) with mean (4.02) and standard deviation (0.84) which means that the research sample Approval of the presence of Competitive environment of the company

- The degree of managers' opinion of Competitive profitability of the company with degree(agree) with mean (4.06) and standard deviation (0.84) which means that the research sample Approval of the presence of Competitive profitability of the company

- (strategic management \& technology management)are the most factors that achieves more competitive advantage

- there is a strong significant correlation between the two factors (strategic management $\&$ technology management)

\section{Recommendations}

- Companies must interested in The strategic analysis of IT as a competitive factor

- Companies must improve strategic management 
- Companies must look after their Competitive environment

- Companies must look after their Competitive profitability

\section{References}

Akdag, C., and Zineldin, M. (2011). Strategic positioning and quality determinants in banking service. The TQM Journal, 23(4), 446-457.

Andrews, K. R. (1980). The Concept of Corporate Strategy, (3rd ed.). Homewood, Ill: 1965; Homewood.

Ansoff, H. L., 1988. The New Corporate Strategy. Wiley, New York.

Arsham, H. (2005). Applied Management Science: Making Good Strategic Decisions. Retrieved December 9, 2005, from: http://home.ubalt.edu/ntsbarsh/opre640/opre640.htm.

Bauer, H., Hammerschmidt, M. and Falk, T. (2005). Measuring the quality of e-banking portals. International Journal of Bank Marketing, 23(2), 153-75.

Boone, L.E., and Kurtz, D.L. (2009). Contemporary Business Update. Chicago, John Wiley and Sons

Bower, J. L., 1982 Managing the resource allocation process. Harvard Business School Press, Boston, MA.

Burgelman, R, A., 1988. Strategy making as a social Learning Process: the case of internal corporate venturing. Inferences $18,74-85$.

Cardullo, M. (1996). Introduction to Managing Technology. Engineering Management Series. (282 pp.). England. Research Studies Press LTD.

Chan P.S. \& Heide, D. (1992). Information Technology and the New Environment: Developing and Sustaining Competitive Advantage. Retrieved from http://www.questia.com/googleScholar.docId $=5000165074$

Cöster, Mathias (2005). Beyond IT and Productivity - How Digitization Transformed the Graphic Industry, lic.avh. No. 1183, IDA-EIS, Universitetet och Tekniska Högskolan i Linköping.

Day, G. S., \& Wensley, R. (1988). Assessing advantage: A framework for diagnosing competitive superiority. The Journal of Marketing, 52(2), 1-20.

Dabholkar, P. (1994). Technology based service delivery, Advances in Services Management, 3, 241-71. Dabholkar, P. and Bagozzi, R. (2002). An attitudinal model of technology-based self-service: moderating effects of consumer's traits and situational factors. Journal of Academy of Marketing Science, 30 (3), 184-201.

Dabholkar, P. (1994). Technology based service delivery, Advances in Services Management, 3, 241-71. Dabholkar, P. and Bagozzi, R. (2002). An attitudinal model of technology-based self-service: moderating effects of consumer's traits and situational factors. Journal of Academy of Marketing Science, 30 (3), 184-201.

Drucker, P. (1954). The Practice of Management. New York. Harper.

Drucker, P. (1994). Post-capitalist Society. Oxford. Butterworth Heinemann.
Goold, M., Quinn, J. J., 1993 Strategic Control; Establishing Milestones for Long Term Performance. AddisonWesley, Reading, MA.

Gummesson, E. (1991). Qualitative Methods in Management Research, Sage Publications

Hamel, G. (1996). Strategy as Revolution. Harvard Business Review, July-August, 69-82. Hamel, G. (2000). Leading the Revolution. Boston: Harvard Business School Press. Han, K., Kim, N., and Srivastava, K. (1998). Market orientation and organizational performance: is innovation a missing link? The Journal of Marketing, 62(4), 30-

Henderson, S. (2011). The development of competitive advantage through sustainable event management. Worldwide Hospitality and Tourism Themes, 3(3), 245-257. Huff, S. (1988). Supporting competitive strategy with information technology. Business Quarterly, 53(2), 3739.

Hill, C. W. L., Jones, G. R. , 1999. Strategic Management: An Integrative Approach. $4^{\text {th }}$ ed. Houghton Mifflin, Boston, MA.

Hopp, W. (2004). 50th Anniversary Article, Fifty Years of Management Science. Management Science. Vol. 50. No. 1. pp. 1-7.

J.C. Mingers, 1995. What is the distinctive nature and value of IS as a discipline?' Systemist, 17, 1, 18-22. ongoing debates on IS and the IS discipline

Johannsen, H., \& Page, G.T. (1986). International Dictionary of Management. (3rd ed.). London. Kogan Page.

Jonach, S. and Sommerlatte, T. (1999). The Innovation Premium: How the Next-Generation Companies are Achieving Peak Performance and Profitability. Reading, MA, Perseus Books.

Keller, Christina (2005). Virtual Learning Environments in higher education A study of students' acceptance of educational technology, lic.-avh. No. 1167 IDA-EIS, Universitetet och Tekniska Högskolan i Linköping.

Kothari, C. R. (2007). Research methodology: A step-bystep guide for beginners. New Delhi, New Age International. Kotler, P. (1998). Marketing Management: Analysis, Planning, Implementation and Control. New Dehli, Prentice Hall of India.

Lawler E. E. (III) (2008). Talent: Making people Your Competitive Advantage. US, John Wiley \& Sons. Li, J. J., and Zhou, K. Z. (2010). How foreign firms achieve competitive advantage in the Chinese emerging economy: Managerial ties and market orientation. Journal of Business Research, 63(8), 856-862 Lipsey, R. G. (1987). An Introduction to Positive Economics. Boston, USA, Irwin McGraw-Hill.

Lockyer, B. (2011). Competitive Advantage of Customer Service for SME. The EDGE 3.12, (December), Retrieved from http://www.theedge.me/competitive-advantage-of-customer-service-for-smes/ Magutu, P., Mwangi, M., Nyaoga, R., Ondimu,

Langefors, B. (1993). Essays on infology. Gothenburg studies in information systems. Göteborg: Department of Information Systems, University of Göteborg

Lorange, P. Vancil, 1977. Strategic Planning Systems. Prentice- Hall, Englewood Cliffs, NJ.

Lundeberg, M., Mårtensson, P., Sannes, R., \& Sundgren, B. (1995). Information Management as a Field. In 
Dahlbom, B. (Ed.). The Infological Equation: Essays in Honor of Börje Langefors. Gothenburg: Dep. of Informatics, School of Economics and Commercial Law, pp. 195-209.

Magutu, P., Mwangi, M., Nyaoga, R., Ondimu, G., Kagu, M., Mutai, K., Kilonzo, H. and Nthenya, P. (2011). ECommerce Products and Services in the Banking Industry: The Adoption and Usage in Commercial Banks in Kenya. Journal of Electronic Banking Systems, 2011, retrieved from http://www.ibimapublishing.com/journals/JEBS/jebs.html Article ID 678961, DOI: 10.5171/2011. 678961

Miller, D. (1987). The structural and environmental correlates of business strategy. Strategic management journal, 8(1), 55-76.

Miller, D. (1988). Relating Porter's business strategies to environment and structure: Analysis and performance implications. Academy of management Journal, 31(June), 280-308.

Mason, R., McKenney, \& Copeland, D. (1997). An Historical Method for MIS Research: Steps and Assumptions. MIS Quarterly. September 1997: pp. 307-319.

Mintzberg, H., 1978. Patterns in strategy formation. Management Science 24, 934- 948.

Mintzberg, H., \& Quinn, J. (1991). The Strategy Process: Concepts, Contexts, Cases, Prentice Hall, Inc., Englewood Cliffs, NJ.

Mintzberg, H. , 1994. The fall and rise of strategic Planning. Harvard Business Review 72, 107- 114.

Nair M.R. (n.d.) Retrieved from http://mrnair.articlesbase.com/strategic-planning-articles/informationtechnology-and-sustained-competitive-advantage925286.html\#ixzz1ZY2Gbt6y Njoya, E. T., and Niemeier, H. M. (2011). Do dedicated low-cost passenger terminals create competitive advantages for airports? Research in Transportation Business \& Management.

Narayanan, V., Fahey, L. , 1982. The micro- politics of strategy formulation. Academy of Management Review 7, 25- 34.

Nilsson, F. \& Rapp, B. (2005). Understanding competitive advantage. Berlin London. Springer. 230 pp.

Norman, R., 1985 Developing capabilities for organizational learning. In: Pennings, J , M. (Ed.) Organizational strategy and change: New views on Formulating and implementing Strategic decisions. Jossey- Bass, San Francisco.

O.E. Williamson (1981), 'the economics of organization: the transaction cost approach', The American Journal of Sociology, 87, 3, 548-577; 'The theory of the firm as governance structure: from choice to contract', Journal of Economic Perspectives, 16, 3, 2002, 171-195.

Orlikowski, W. (1992a) The Duality of Technology: Rethinking the Concept of Technology in Organizations. Organization Science. Vol. 3, No. 3, pp. 398-427.

Orlikowski, W. (1995). Shaping Electronic Communication: The Metastructuring of Technology in the Context of Use. Organization Science. Vol. 6, No. 4, July-Augusti 1995. pp. 423-444.

Orlikowski, W. (2000). Using Technology and Constituting Structures: A Practice Lens for Studying Technology in Organizations. Organization Science. Vol. 11, No. 4 (July- August 2000), pp. 404-428.
Orlikowski, W., \& Gash, D. (1992). Changing Frames: Understanding Technological Change in Organizations. Center for Information Systems Research. Massachusetts Institute of Technology. WP. No. 236.

Orlikowksi, W., \& Iacono, S. (2001). Research Commentary: Desperately Seeking the "IT" in IT Research - A Call to Theorizing the IT Artifact. Information Systems Research. Vol. 12, No. 2, June 2001, pp. 121-134.

O'Shannassy, T. (1999). Lessons from the Evolution of the Strategy Paradigm. RMIT Business, No. WP 99/20 (November 1999), School of Management. ISNN 10387448.

Ochieng, O. (2010). The banking survey in Kenya. The overall ranking of banks. Nairobi, ORB Business Publishers Ojung'a S. (2005). A survey of E-Commerce in Commercial Banks in Kenya. Unpublished MBA Research Project, University of Nairobi.

Parasuraman, A., and Colby, C.L. (2001), Techno-Ready Marketing: How and Why Your Customers Adopt Technology, New York, NY, Free Press

. Pearce J. A. (II) and Robinson R. B. (Jr), (2005). Strategic Management: Formulation, Implementation, and Control (10th Ed.). Boston, USA, Irwin McGraw-Hill.

Peters, T. (1987) Thriving on Chaos, New York, Harper \& Row

Porter, M. E., 1980 Competitive Strategy. Free Press, New York.

Porter, M. (1991). Towards a Dynamic Theory of Strategy. Strategic Management Journal, Vol.12, Special Issue: Fundamental Research Issues in Strategy and Economics. (Winter, 1991). pp. 95-117.

R.H. Coase (1937,) the nature of the firm', Economica, 4, 16, 386-405. Reprinted in O.E. Williamson and S. Winter (1991), eds, The Nature of the Firm: Origins, Evolution, Development. New York: Oxford University Press, , 18-33.

Richards, M. D., 1986. Setting Strategic goals and objectives, $2^{\text {nd }}$ ed. West Publishing, St. Paul, MN.

Sällberg, Henrik (2004). On the value of customer loyalty programs - a study of point programs and switching costs, lic-avh. No. 1116, IDA-EIS Universitetet och Tekniska Högskolan i Linköping.

Selznic, P. (1957). Ledarship in Administration. New York. Harper and Row

Schendel, D., Hofer, C., 1979. Strategic Management: A new view of Business Policy and planning. Little Brown, Boston, MA.

N. Venkatraman (1991), 'IT induced business re-configuration', in M.S. Scott Morton, ed., The Corporation of the 1990s Information Technology and Organizational Transformation, Oxford University Press, New York, $122-158$.

Wang, Z (2004), Capacity-Constrained Production-Inventory Systems - Modelling and Analysis in both a Traditional and an EBusiness Context doktorsavhandling 889, IDA-EIS, Universitetet och Tekniska Högskolan i Linköping.

Whittington, R. (2001). What is strategy - and does it matter? (2nd ed.), London, Thomson Learning. 155 pp. 


\section{Appendix}

First axis

\begin{tabular}{|c|c|c|}
\hline & & strategic management \\
\hline \multirow{3}{*}{$\begin{array}{l}\text { Strategic management deals with internal and external } \\
\text { factors }\end{array}$} & Pearson Correlation & $.891^{\text {** }}$ \\
\hline & Sig. (2-tailed) & .000 \\
\hline & $\mathrm{N}$ & 18 \\
\hline \multirow{3}{*}{$\begin{array}{l}\text { one can consider other managers, business goals and } \\
\text { competitive resources }\end{array}$} & Pearson Correlation & $.860^{* * *}$ \\
\hline & Sig. (2-tailed) & .000 \\
\hline & $\mathrm{N}$ & 18 \\
\hline \multirow{3}{*}{$\begin{array}{l}\text { both internal and external factors can change over time, } \\
\text { changing the premises of competition and making the } \\
\text { strategic management task much more complex }\end{array}$} & Pearson Correlation & $.892^{* * *}$ \\
\hline & Sig. (2-tailed) & .000 \\
\hline & $\mathrm{N}$ & 18 \\
\hline \multirow{3}{*}{$\begin{array}{l}\text { The strategic manager has to consider the combination of } \\
\text { internal and external factors to be able to achieve com- } \\
\text { petitive advantages. }\end{array}$} & Pearson Correlation & $.956^{* *}$ \\
\hline & Sig. (2-tailed) & .000 \\
\hline & $\mathrm{N}$ & 18 \\
\hline \multirow{3}{*}{$\begin{array}{l}\text { the competitive factors may change over time and affect } \\
\text { the strategic manager's choices for competition }\end{array}$} & Pearson Correlation & $.950^{* *}$ \\
\hline & Sig. (2-tailed) & .000 \\
\hline & $\mathrm{N}$ & 18 \\
\hline \multirow{3}{*}{$\begin{array}{l}\text { The strength of institutional control contributes to the } \\
\text { continuity of the organization and its avoidance in crises }\end{array}$} & Pearson Correlation & $.965^{* *}$ \\
\hline & Sig. (2-tailed) & .000 \\
\hline & $\mathrm{N}$ & 18 \\
\hline \multirow{3}{*}{$\begin{array}{l}\text { Pay attention to values of information and communica- } \\
\text { tion systems }\end{array}$} & Pearson Correlation & $.993^{* *}$ \\
\hline & Sig. (2-tailed) & .000 \\
\hline & $\mathrm{N}$ & 18 \\
\hline \multirow{3}{*}{$\begin{array}{l}\text { Availability of clear legislation related to investment, } \\
\text { taxation and customs }\end{array}$} & Pearson Correlation & $.965^{* *}$ \\
\hline & Sig. (2-tailed) & .000 \\
\hline & $\mathrm{N}$ & 18 \\
\hline \multirow{3}{*}{$\begin{array}{l}\text { The availability of international or local accounting and } \\
\text { auditing standards. }\end{array}$} & Pearson Correlation & $.932^{* *}$ \\
\hline & Sig. (2-tailed) & .000 \\
\hline & $\mathrm{N}$ & 18 \\
\hline \multirow{3}{*}{$\begin{array}{l}\text { Keeping up with the speed of technical development in } \\
\text { the field of work. }\end{array}$} & Pearson Correlation & $.993^{* *}$ \\
\hline & Sig. (2-tailed) & .000 \\
\hline & $\mathrm{N}$ & 18 \\
\hline
\end{tabular}




\section{Second axis}

\begin{tabular}{|c|c|c|}
\hline & & technology management \\
\hline \multirow{3}{*}{$\begin{array}{l}\text { The use of the computer in general in the company has the first } \\
\text { role in reaching technological innovations }\end{array}$} & Pearson Correlation & $.857^{* *}$ \\
\hline & Sig. (2-tailed) & .000 \\
\hline & $\mathrm{N}$ & 18 \\
\hline \multirow{3}{*}{$\begin{array}{l}\text { Cooperation with scientific academic institutions helps in the } \\
\text { development of technological innovation }\end{array}$} & Pearson Correlation & $.599^{* *}$ \\
\hline & Sig. (2-tailed) & .009 \\
\hline & $\mathrm{N}$ & 18 \\
\hline \multirow{3}{*}{$\begin{array}{l}\text { The technical databases adopted by the establishment are an } \\
\text { essential element in their success in technological innovation }\end{array}$} & Pearson Correlation & $.893^{* *}$ \\
\hline & Sig. (2-tailed) & .000 \\
\hline & $\mathrm{N}$ & 18 \\
\hline \multirow{3}{*}{$\begin{array}{l}\text { Increasing the number of technicians specialized in research } \\
\text { and development leads to increased technological innovation }\end{array}$} & Pearson Correlation & $.928^{* *}$ \\
\hline & Sig. (2-tailed) & .000 \\
\hline & $\mathrm{N}$ & 18 \\
\hline \multirow{3}{*}{$\begin{array}{l}\text { The participation of individuals in training programs and sci- } \\
\text { entific conferences has been a major cause of technological } \\
\text { innovation }\end{array}$} & Pearson Correlation & $.901^{* *}$ \\
\hline & Sig. (2-tailed) & .000 \\
\hline & $\mathrm{N}$ & 18 \\
\hline \multirow{3}{*}{$\begin{array}{l}\text { Cooperation with the scientific advisory bodies and organiza- } \\
\text { tions related to the company's industry is a clear contribution } \\
\text { to our technological innovation }\end{array}$} & Pearson Correlation & $.922^{* *}$ \\
\hline & Sig. (2-tailed) & .000 \\
\hline & $\mathrm{N}$ & 18 \\
\hline \multirow{3}{*}{$\begin{array}{l}\text { The abundance of information needed to accomplish research } \\
\text { and development projects in quantity, timing and the appro- } \\
\text { priate type leads to technological innovation in the establish- } \\
\text { ment }\end{array}$} & Pearson Correlation & $.937^{* *}$ \\
\hline & Sig. (2-tailed) & .000 \\
\hline & $\mathrm{N}$ & 18 \\
\hline \multirow{3}{*}{$\begin{array}{l}\text { The existence of channels of information exchange inside and } \\
\text { outside the facility has a great impact on technological inno- } \\
\text { vation. }\end{array}$} & Pearson Correlation & $.922^{* *}$ \\
\hline & Sig. (2-tailed) & .000 \\
\hline & $\mathrm{N}$ & 18 \\
\hline \multirow{3}{*}{$\begin{array}{l}\text { The existence of prior control and feedback of information } \\
\text { contributes to technological innovation }\end{array}$} & Pearson Correlation & $.882^{* *}$ \\
\hline & Sig. (2-tailed) & .000 \\
\hline & $\mathrm{N}$ & 18 \\
\hline \multirow{3}{*}{$\begin{array}{l}\text { The Internet and the various sites where our facilities have } \\
\text { helped us in. Develop our technological innovation }\end{array}$} & Pearson Correlation & $.718^{* *}$ \\
\hline & Sig. (2-tailed) & .001 \\
\hline & $\mathrm{N}$ & 18 \\
\hline
\end{tabular}


Third axis

\begin{tabular}{|c|c|c|}
\hline & & Competitive environment of the company \\
\hline \multirow{3}{*}{$\begin{array}{l}\text { The company can penetrate new mar- } \\
\text { kets }\end{array}$} & Pearson Correlation & $.956^{* *}$ \\
\hline & Sig. (2-tailed) & .000 \\
\hline & $\mathrm{N}$ & 18 \\
\hline \multirow{3}{*}{$\begin{array}{l}\text { The company is innovating new } \\
\text { products }\end{array}$} & Pearson Correlation & $.962^{* *}$ \\
\hline & Sig. (2-tailed) & .000 \\
\hline & $\mathrm{N}$ & 18 \\
\hline \multirow{3}{*}{$\begin{array}{l}\text { The company presented more than } \\
\text { one product }\end{array}$} & Pearson Correlation & $.990^{* *}$ \\
\hline & Sig. (2-tailed) & .000 \\
\hline & $\mathrm{N}$ & 18 \\
\hline \multirow{3}{*}{$\begin{array}{l}\text { The company maintains its position } \\
\text { in the local and foreign markets }\end{array}$} & Pearson Correlation & $.962^{* *}$ \\
\hline & Sig. (2-tailed) & .000 \\
\hline & $\mathrm{N}$ & 18 \\
\hline \multirow{3}{*}{$\begin{array}{l}\text { The company has obtained good } \\
\text { manufacturing requirements }\end{array}$} & Pearson Correlation & $.929^{* *}$ \\
\hline & Sig. (2-tailed) & .000 \\
\hline & $\mathrm{N}$ & 18 \\
\hline \multirow{3}{*}{$\begin{array}{l}\text { The company seeks to reach strategic } \\
\text { alliances within it }\end{array}$} & Pearson Correlation & $.990^{* *}$ \\
\hline & Sig. (2-tailed) & .000 \\
\hline & $\mathrm{N}$ & 18 \\
\hline \multirow{3}{*}{$\begin{array}{l}\text { The company is working to reduce } \\
\text { cost rates }\end{array}$} & Pearson Correlation & $.859^{* *}$ \\
\hline & Sig. (2-tailed) & .000 \\
\hline & $\mathrm{N}$ & 18 \\
\hline \multirow[t]{3}{*}{ The company seeks quality marks } & Pearson Correlation & $.601^{* *}$ \\
\hline & Sig. (2-tailed) & .008 \\
\hline & $\mathrm{N}$ & 18 \\
\hline \multirow{3}{*}{$\begin{array}{l}\text { There is diversity and renewal of the } \\
\text { ways and methods of work at the } \\
\text { company }\end{array}$} & Pearson Correlation & $.897^{* *}$ \\
\hline & Sig. (2-tailed) & .000 \\
\hline & $\mathrm{N}$ & 18 \\
\hline \multirow{3}{*}{$\begin{array}{l}\text { The company promotes innovative } \\
\text { behaviors }\end{array}$} & Pearson Correlation & $.913^{* *}$ \\
\hline & Sig. (2-tailed) & .000 \\
\hline & $\mathrm{N}$ & 18 \\
\hline
\end{tabular}




\section{Fourth axis}

\begin{tabular}{|c|c|c|}
\hline & & Competitive profitability of the company \\
\hline \multirow{3}{*}{$\begin{array}{l}\text { There are financial provisions for all } \\
\text { fields of the company }\end{array}$} & Pearson Correlation & $.933^{* *}$ \\
\hline & Sig. (2-tailed) & .000 \\
\hline & $\mathrm{N}$ & 18 \\
\hline \multirow[t]{3}{*}{ The company achieved high profits } & Pearson Correlation & $.750^{* * *}$ \\
\hline & Sig. (2-tailed) & .000 \\
\hline & $\mathrm{N}$ & 18 \\
\hline \multirow{3}{*}{$\begin{array}{l}\text { Employees receive high-value sala- } \\
\text { ries }\end{array}$} & Pearson Correlation & $.856^{* *}$ \\
\hline & Sig. (2-tailed) & .000 \\
\hline & $\mathrm{N}$ & 18 \\
\hline \multirow{3}{*}{$\begin{array}{l}\text { Availability of funds in a timely man- } \\
\text { ner }\end{array}$} & Pearson Correlation & $.957^{* *}$ \\
\hline & Sig. (2-tailed) & .000 \\
\hline & $\mathrm{N}$ & 18 \\
\hline \multirow{3}{*}{$\begin{array}{l}\text { The company provides training and } \\
\text { qualification opportunities for em- } \\
\text { ployees at the expense of the com- } \\
\text { pany }\end{array}$} & Pearson Correlation & $.956^{* *}$ \\
\hline & Sig. (2-tailed) & .000 \\
\hline & $\mathrm{N}$ & 18 \\
\hline \multirow{3}{*}{$\begin{array}{l}\text { It is noted that the productivity } \\
\text { growth rates of the company's em- } \\
\text { ployees are high }\end{array}$} & Pearson Correlation & $.945^{* * *}$ \\
\hline & Sig. (2-tailed) & .000 \\
\hline & $\mathrm{N}$ & 18 \\
\hline \multirow{3}{*}{$\begin{array}{l}\text { There is an increase in the value of } \\
\text { exports to EU countries }\end{array}$} & Pearson Correlation & $.976^{* *}$ \\
\hline & Sig. (2-tailed) & .000 \\
\hline & $\mathrm{N}$ & 18 \\
\hline \multirow[t]{3}{*}{ Relatively high exports to imports } & Pearson Correlation & $.945^{* *}$ \\
\hline & Sig. (2-tailed) & .000 \\
\hline & $\mathrm{N}$ & 18 \\
\hline \multirow{3}{*}{$\begin{array}{l}\text { There is a growth in overall sales of } \\
\text { the company }\end{array}$} & Pearson Correlation & $.919^{* *}$ \\
\hline & Sig. (2-tailed) & .000 \\
\hline & $\mathrm{N}$ & 18 \\
\hline \multirow{3}{*}{$\begin{array}{l}\text { We note the growth of the market } \\
\text { share in the local and foreign mar- } \\
\text { kets }\end{array}$} & Pearson Correlation & $.782^{* * *}$ \\
\hline & Sig. (2-tailed) & .000 \\
\hline & $\mathrm{N}$ & 18 \\
\hline
\end{tabular}


internal consistency

\begin{tabular}{|l|l|l|}
\hline \multirow{3}{*}{ strategic management } & & Total Degree \\
\hline \multirow{3}{*}{ technology management } & Pearson Correlation & $.984^{* *}$ \\
\cline { 2 - 3 } & Sig. (2-tailed) & .000 \\
\cline { 2 - 3 } & $\mathrm{N}$ & 18 \\
\hline \multirow{3}{*}{$\begin{array}{l}\text { Competitive environment of the } \\
\text { company }\end{array}$} & Pearson Correlation & $.990^{* *}$ \\
\cline { 2 - 3 } & Sig. (2-tailed) & .000 \\
\cline { 2 - 3 } & $\mathrm{N}$ & 18 \\
\hline \multirow{2}{*}{$\begin{array}{l}\text { Competitive profitability of the } \\
\text { company }\end{array}$} & Sig. (2-tailed) & $.990^{* *}$ \\
\cline { 2 - 3 } & $\mathrm{N}$ & .000 \\
\cline { 2 - 3 } & Pearson Correlation & 18 \\
\cline { 2 - 3 } & $\mathrm{N}$ & $.982^{* *}$ \\
\hline
\end{tabular}


First axis

\begin{tabular}{|c|c|c|c|c|c|}
\hline \multicolumn{6}{|l|}{ Descriptive Statistics } \\
\hline & $\mathrm{N}$ & Minimum & Maximum & Mean & Std. Deviation \\
\hline $\begin{array}{l}\text { Strategic management deals } \\
\text { with internal and external factors }\end{array}$ & 18 & 3 & 5 & 4.17 & .786 \\
\hline $\begin{array}{l}\text { one can consider other manag- } \\
\text { ers, business goals and competi- } \\
\text { tive resources }\end{array}$ & 18 & 3 & 5 & 4.17 & .618 \\
\hline $\begin{array}{l}\text { both internal and external factors } \\
\text { can change over time, changing } \\
\text { the premises of competition and } \\
\text { making the strategic manage- } \\
\text { ment task much more complex }\end{array}$ & 18 & 3 & 5 & 4.22 & .878 \\
\hline $\begin{array}{l}\text { The strategic manager has to } \\
\text { consider the combination of in- } \\
\text { ternal and external factors to be } \\
\text { able to achieve competitive ad- } \\
\text { vantages. }\end{array}$ & 18 & 3 & 5 & 4.00 & .840 \\
\hline $\begin{array}{l}\text { the competitive factors may } \\
\text { change over time and affect the } \\
\text { strategic manager's choices for } \\
\text { competition }\end{array}$ & 18 & 3 & 5 & 3.89 & .832 \\
\hline $\begin{array}{l}\text { The strength of institutional con- } \\
\text { trol contributes to the continuity } \\
\text { of the organization and its avoid- } \\
\text { ance in crises }\end{array}$ & 18 & 3 & 5 & 4.00 & .840 \\
\hline $\begin{array}{l}\text { Pay attention to values of infor- } \\
\text { mation and communication sys- } \\
\text { tems }\end{array}$ & 18 & 3 & 5 & 3.94 & .802 \\
\hline $\begin{array}{l}\text { Availability of clear legislation } \\
\text { related to investment, taxation } \\
\text { and customs }\end{array}$ & 18 & 3 & 5 & 4.00 & .840 \\
\hline $\begin{array}{l}\text { The availability of international } \\
\text { or local accounting and auditing } \\
\text { standards. }\end{array}$ & 18 & 2 & 5 & 3.83 & .924 \\
\hline $\begin{array}{l}\text { Keeping up with the speed of } \\
\text { technical development in the } \\
\text { field of work. }\end{array}$ & 18 & 3 & 5 & 3.94 & .802 \\
\hline Valid N (listwise) & 18 & & & & \\
\hline
\end{tabular}

Second axis 


\begin{tabular}{|c|c|c|c|c|c|}
\hline \multicolumn{6}{|l|}{ Descriptive Statistics } \\
\hline & $\mathrm{N}$ & Minimum & Maximum & Mean & Std. Deviation \\
\hline $\begin{array}{l}\text { The use of the computer in gen- } \\
\text { eral in the company has the first } \\
\text { role in reaching technological } \\
\text { innovations }\end{array}$ & 18 & 3 & 5 & 4.28 & .826 \\
\hline $\begin{array}{l}\text { Cooperation with scientific aca- } \\
\text { demic institutions helps in the } \\
\text { development of technological } \\
\text { innovation }\end{array}$ & 18 & 2 & 5 & 3.94 & .873 \\
\hline $\begin{array}{l}\text { The technical databases adopted } \\
\text { by the establishment are an es- } \\
\text { sential element in their success } \\
\text { in technological innovation }\end{array}$ & 18 & 3 & 5 & 4.22 & .878 \\
\hline $\begin{array}{l}\text { Increasing the number of techni- } \\
\text { cians specialized in research and } \\
\text { development leads to increased } \\
\text { technological innovation }\end{array}$ & 18 & 3 & 5 & 4.11 & .832 \\
\hline $\begin{array}{l}\text { The participation of individuals } \\
\text { in training programs and scien- } \\
\text { tific conferences has been a ma- } \\
\text { jor cause of technological inno- } \\
\text { vation }\end{array}$ & 18 & 3 & 5 & 4.06 & .873 \\
\hline $\begin{array}{l}\text { Cooperation with the scientific } \\
\text { advisory bodies and organiza- } \\
\text { tions related to the company's in- } \\
\text { dustry is a clear contribution to } \\
\text { our technological innovation }\end{array}$ & 18 & 3 & 5 & 4.17 & .857 \\
\hline $\begin{array}{l}\text { The abundance of information } \\
\text { needed to accomplish research } \\
\text { and development projects in } \\
\text { quantity, timing and the appro- } \\
\text { priate type leads to technological } \\
\text { innovation in the establishment }\end{array}$ & 18 & 3 & 5 & 4.11 & .832 \\
\hline $\begin{array}{l}\text { The existence of channels of in- } \\
\text { formation exchange inside and } \\
\text { outside the facility has a great } \\
\text { impact on technological innova- } \\
\text { tion. }\end{array}$ & 18 & 3 & 5 & 4.17 & .857 \\
\hline $\begin{array}{l}\text { The existence of prior control } \\
\text { and feedback of information } \\
\text { contributes to technological in- } \\
\text { novation }\end{array}$ & 18 & 2 & 5 & 3.89 & .963 \\
\hline $\begin{array}{l}\text { The Internet and the various sites } \\
\text { where our facilities have helped } \\
\text { us in. Develop our technological } \\
\text { innovation }\end{array}$ & 18 & 2 & 5 & 3.78 & 1.003 \\
\hline Valid N (listwise) & 18 & & & & \\
\hline
\end{tabular}


Third axis

\begin{tabular}{|c|c|c|c|c|c|}
\hline \multicolumn{6}{|l|}{ Descriptive Statistics } \\
\hline & $\mathrm{N}$ & Minimum & Maximum & Mean & Std. Deviation \\
\hline $\begin{array}{l}\text { The company can penetrate new } \\
\text { markets }\end{array}$ & 18 & 3 & 5 & 3.89 & .832 \\
\hline $\begin{array}{l}\text { The company is innovating new } \\
\text { products }\end{array}$ & 18 & 3 & 5 & 4.00 & .840 \\
\hline $\begin{array}{l}\text { The company presented more } \\
\text { than one product }\end{array}$ & 18 & 3 & 5 & 3.94 & .802 \\
\hline $\begin{array}{l}\text { The company maintains its posi- } \\
\text { tion in the local and foreign } \\
\text { markets }\end{array}$ & 18 & 3 & 5 & 4.00 & .840 \\
\hline $\begin{array}{l}\text { The company has obtained good } \\
\text { manufacturing requirements }\end{array}$ & 18 & 2 & 5 & 3.83 & .924 \\
\hline $\begin{array}{l}\text { The company seeks to reach } \\
\text { strategic alliances within it }\end{array}$ & 18 & 3 & 5 & 3.94 & .802 \\
\hline $\begin{array}{l}\text { The company is working to re- } \\
\text { duce cost rates }\end{array}$ & 18 & 3 & 5 & 4.28 & .826 \\
\hline $\begin{array}{l}\text { The company seeks quality } \\
\text { marks }\end{array}$ & 18 & 2 & 5 & 3.94 & .873 \\
\hline $\begin{array}{l}\text { There is diversity and renewal of } \\
\text { the ways and methods of work at } \\
\text { the company }\end{array}$ & 18 & 3 & 5 & 4.22 & .878 \\
\hline $\begin{array}{l}\text { The company promotes innova- } \\
\text { tive behaviors }\end{array}$ & 18 & 3 & 5 & 4.11 & .832 \\
\hline Valid N (listwise) & 18 & & & & \\
\hline
\end{tabular}


Fourth axis

\begin{tabular}{|c|c|c|c|c|c|}
\hline \multicolumn{6}{|c|}{ Descriptive Statistics } \\
\hline & $\mathrm{N}$ & Minimum & Maximum & Mean & Std. Deviation \\
\hline $\begin{array}{l}\text { There are financial provisions } \\
\text { for all fields of the company }\end{array}$ & 18 & 3 & 5 & 4.06 & .873 \\
\hline $\begin{array}{l}\text { The company achieved high } \\
\text { profits }\end{array}$ & 18 & 3 & 5 & 4.06 & .725 \\
\hline $\begin{array}{l}\text { Employees receive high-value } \\
\text { salaries }\end{array}$ & 18 & 3 & 5 & 4.28 & .895 \\
\hline $\begin{array}{l}\text { Availability of funds in a timely } \\
\text { manner }\end{array}$ & 18 & 3 & 5 & 4.06 & .802 \\
\hline $\begin{array}{l}\text { The company provides training } \\
\text { and qualification opportunities } \\
\text { for employees at the expense of } \\
\text { the company }\end{array}$ & 18 & 3 & 5 & 4.00 & .840 \\
\hline $\begin{array}{c}\text { It is noted that the productivity } \\
\text { growth rates of the company's } \\
\text { employees are high }\end{array}$ & 18 & 3 & 5 & 4.11 & .832 \\
\hline $\begin{array}{c}\text { There is an increase in the value } \\
\text { of exports to EU countries }\end{array}$ & 18 & 3 & 5 & 4.06 & .802 \\
\hline $\begin{array}{l}\text { Relatively high exports to im- } \\
\text { ports }\end{array}$ & 18 & 3 & 5 & 4.11 & .832 \\
\hline $\begin{array}{l}\text { There is a growth in overall } \\
\text { sales of the company }\end{array}$ & 18 & 2 & 5 & 3.94 & .938 \\
\hline $\begin{array}{l}\text { We note the growth of the mar- } \\
\text { ket share in the local and for- } \\
\text { eign markets }\end{array}$ & 18 & 2 & 5 & 3.89 & .900 \\
\hline Valid N (listwise) & 18 & & & & \\
\hline
\end{tabular}

Hypotheses

Factor Analysis

\begin{tabular}{|c|c|c|}
\hline \multicolumn{3}{|l|}{ Communalities } \\
\hline & Initial & Extraction \\
\hline strategic management & 1.000 & .979 \\
\hline technology management & 1.000 & .981 \\
\hline $\begin{array}{l}\text { Competitive environment of the } \\
\text { company }\end{array}$ & 1.000 & .968 \\
\hline $\begin{array}{l}\text { Competitive profitability of the } \\
\text { company }\end{array}$ & 1.000 & .964 \\
\hline
\end{tabular}




\begin{tabular}{|c|c|c|c|c|c|c|}
\hline \multicolumn{7}{|c|}{ Total Variance Explained } \\
\hline \multirow[b]{2}{*}{ Component } & \multicolumn{3}{|c|}{ Initial Eigenvalues } & \multicolumn{3}{|c|}{ Extraction Sums of Squared Loadings } \\
\hline & Total & $\%$ of Variance & Cumulative $\%$ & Total & $\%$ of Variance & Cumulative $\%$ \\
\hline 1 & .003 & .071 & 99.965 & 3.892 & 97.310 & 97.310 \\
\hline 2 & .103 & 2.584 & 99.894 & & & \\
\hline 3 & 3.892 & 97.310 & 97.310 & & & \\
\hline 4 & .001 & .035 & 100.000 & & & \\
\hline \multicolumn{4}{|c|}{ Extraction Method: Principal Component Analysis. } & & & \\
\hline
\end{tabular}

\begin{tabular}{|l|l|}
\hline Component Matrix $^{\mathrm{a}}$ & Component \\
\hline & 1 \\
\hline strategic management & .989 \\
\hline technology management & .990 \\
\hline Competitive environment of the company & .984 \\
\hline Competitive profitability of the company & .982 \\
\hline Extraction Method: Principal Component Analysis. \\
\hline A.1 components extracted. \\
\hline
\end{tabular}

\begin{tabular}{|c|c|c|c|}
\hline \multicolumn{4}{|l|}{ Correlations } \\
\hline & & $\begin{array}{l}\text { strategic manage- } \\
\text { ment }\end{array}$ & $\begin{array}{l}\text { technology man- } \\
\text { agement }\end{array}$ \\
\hline \multirow[t]{3}{*}{ strategic management } & Pearson Correlation & 1 & $.951^{* *}$ \\
\hline & Sig. (2-tailed) & & .000 \\
\hline & $\mathrm{N}$ & 18 & 18 \\
\hline \multirow[t]{3}{*}{ technology management } & Pearson Correlation & $.951^{* *}$ & 1 \\
\hline & Sig. (2-tailed) & .000 & \\
\hline & $\mathrm{N}$ & 18 & 18 \\
\hline **. Correlation is signific & the 0.01 level (2-taile & & \\
\hline
\end{tabular}

